Research articles

\title{
Effect of La-Substituted Barium Hexaferrite on the Structural Characteristics and Magnetic Properties for Microwave Absorbing Material
}

\author{
Yana Taryana1, Yosef Sarwanto², Wisnu Ari Adi2* \\ ${ }^{1}$ Research Center for Electronic and Telecommunication, Indonesian Institute of Sciences, Bandung, 40135 Indonesia \\ ${ }^{2}$ Center for Science and Technology of Advanced Materials, Kawasan Puspiptek Serpong, Tangerang Selatan, 15314, Indonesia
}

\begin{tabular}{l}
\hline Article info \\
\hline Keywords: \\
Barium hexaferrite \\
$\mathrm{Ba}_{1-\mathrm{x}} \mathrm{La}_{\mathrm{x}} \mathrm{Fe}_{12} \mathrm{O}_{19}$ \\
La-substitution \\
Structural characteristics \\
Magnetic properties \\
Microwave absorbing material
\end{tabular}

\section{Introduction}

Barium hexagonal ferrite has become an interesting object of research thus far after being able to be used for semi-hard magnet applications in electronic components, magnetic memory, recording media, and in particular as a microwave-absorbing material (MAM)[1-4]. Several electrical components that work at high frequencies experience interference due to these adverse microwaves caused by electric and magnetic fields [5-8]. Therefore, microwave absorbers as the focus of research are considered prevalent due to their wide application. The intrinsic requirement of a material that can act as a microwave absorber includes the material that exhibits complex permeability $\left(\mu_{r}\right)$ and permittivity $\left(e_{r}\right)$ in a single phase $[9,10]$. Starting from a hard magnetic material that has high permeability combined with a few high permittivity rare earth elements, it is expected that this material can fulfill the intrinsic requirements needed as a microwave absorber.

One of the hard magnets is barium hexagonal ferrite, which has high permeability and relatively low permittivity. Barium hexagonal ferrite encompasses highly saturated magnetization, great coercivity, excellent thermal and chemical steadiness, adjustable corrosion, and anisotropy resistance. As a microwave absorbent material, its anisotropy is relatively low [11-14]. One way to reduce the barium hexagonal ferrite anisotropy is to substitute it with different metal elements, especially metals that have high permittivity. Several researchers have developed different compositions of $\mathrm{BaFe}_{12} \mathrm{O}_{19}$, which are substituted by different metallic elements for microwave absorption [15-19]. However, in this study, the substitution of rare earth metal La has been carried out as La has magnetic permeability in the transition configuration in group $f$ and is a dielectric material that has a relatively good permittivity [20-22]. This research was designed to explore the effect of La substitution in barium hexagonal ferrite $\left(\mathrm{BaFe}_{12} \mathrm{O}_{19}\right)$ on structural parameters and magnetic properties transformation. The synthesis of this material used the solids reaction method through the mechanical milling technique. This method is effortless and reasonable, so it is promising to be used in the industrial world.

\section{Experimental Methods}

$\mathrm{Ba}_{1-x} \mathrm{La}_{x} \mathrm{Fe}_{12} \mathrm{O}_{19}$ material preparation was calculated based on stoichiometric principles and used raw materials $\mathrm{La}_{2} \mathrm{O}_{3}(\mathrm{Merck}, 99.9 \%$ purity), $\mathrm{BaCO}_{3}$ (Merck, 99.9\% purity), and $\mathrm{Fe}_{2} \mathrm{O}_{3}$ (Sigma-Aldrich, 99.9\% purity). The method used was a solid reaction through the technique of mechanical milling. According to their respective composition, the three raw materials were mixed and milled for $5 \mathrm{~h}$ in a $50 \mathrm{ml}$ ethanol using a PW-1000 machine with high energy. The milling balls' mass ratio (10 $\mathrm{mm}$ in diameter) to the ingredients is $2: 1$. Then, the milled mixture was dried in an oven at $100{ }^{\circ} \mathrm{C}$ for 6 hours. After the sample had been separated from the milling balls, the samples were manually crushed using a mortal agate to produce powder to be compacted into tablets. The produced tablets were then sintered at a temperature of $1200^{\circ} \mathrm{C}$ for $2 \mathrm{~h}$.

Table 1. Stoichiometric calculation of sample $\mathrm{Ba}_{1-\mathrm{x}} \mathrm{La}_{\mathrm{x}} \mathrm{Fe}_{12} \mathrm{O}_{19}$

\begin{tabular}{clccc}
\hline \multirow{2}{*}{$\begin{array}{c}\text { Composition } \\
\mathbf{x}\end{array}$} & \multicolumn{1}{c}{ Sample Name } & \multicolumn{3}{c}{ Mass of raw material $\mathbf{~ g ) ~}$} \\
\cline { 2 - 5 } & & $\mathbf{B a C O}_{\mathbf{3}}$ & $\mathbf{L a}_{\mathbf{2}} \mathbf{O}_{\mathbf{3}}$ & $\mathbf{F e}_{\mathbf{2}} \mathbf{O}_{\mathbf{3}}$ \\
\hline 0 & $\mathrm{BaFe}_{12} \mathrm{O}_{19}$ & 1.775 & 0.000 & 8.621 \\
0.1 & $\mathrm{Ba}_{0.9} \mathrm{La}_{0.1} \mathrm{Fe}_{12} \mathrm{O}_{19}$ & 1.598 & 0.147 & 8.619 \\
0.2 & $\mathrm{Ba}_{0.8} \mathrm{La}_{0.2} \mathrm{Fe}_{12} \mathrm{O}_{19}$ & 1.420 & 0.293 & 8.618 \\
0.3 & $\mathrm{Ba}_{0.7} \mathrm{La}_{0.3} \mathrm{Fe}_{12} \mathrm{O}_{19}$ & 1.242 & 0.440 & 8.617 \\
0.5 & $\mathrm{Ba}_{0.5} \mathrm{La}_{0.5} \mathrm{Fe}_{12} \mathrm{O}_{19}$ & 0.887 & 0.732 & 8.614 \\
0.7 & $\mathrm{Ba}_{0.3} \mathrm{La}_{0.7} \mathrm{Fe}_{12} \mathrm{O}_{19}$ & 0.532 & 1.025 & 8.612 \\
\hline
\end{tabular}

The Brucker brand was used XRD to determine structural parameter changes since La $^{3+}$ substitution effect existed. An X-ray anode was

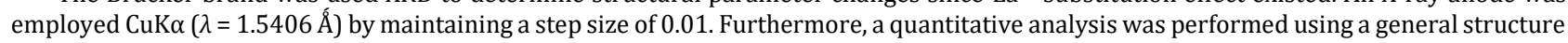

\footnotetext{
*Corresponding author

Email: dwisnuaa@batan.go.id
} 
analysis system (GSAS) program [23-24]. In this work, surface morphology was investigated by using a JEOL JED 350 brand SEM machine, and magnetic properties were studied by using a vibrating sample magnetometer with a range of -1 to 1 tesla.

\section{Results and Discussion}

Figure 1 illustrates the measurement results of the X-ray diffraction pattern (XRD) of the barium hexagonal ferrite sample substitution of

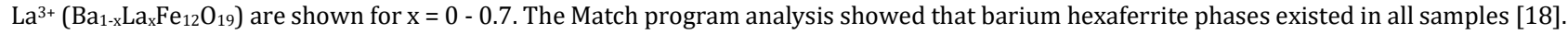
The XRD patterns of all samples correspond strongly to JCPDS data ref: 00-043-0002. Meanwhile, the $x>0.1$ consists of multiple phases.

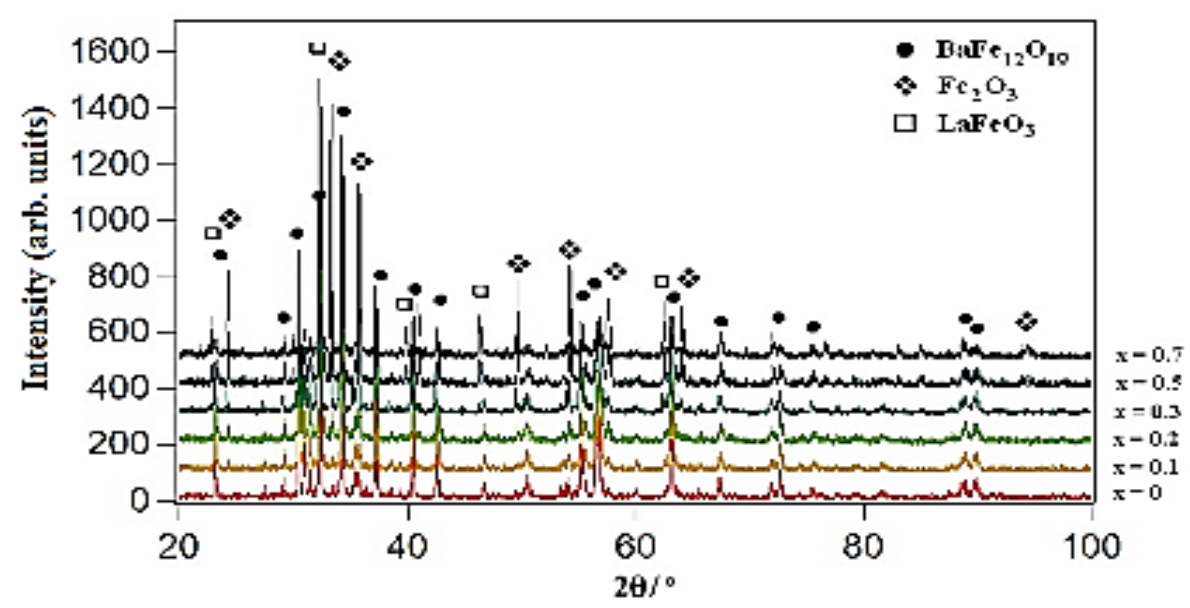

Fig 1. X-ray diffraction patterns of $\mathrm{Ba}_{1-x} \mathrm{La}_{x} \mathrm{Fe}_{12} \mathrm{O}_{19}(\mathrm{x}=0$ - 0.7)

According to the qualitative analysis, it appears that the reaction has succeeded in forming a single-phase $\mathrm{Ba}_{1-\mathrm{x}} \mathrm{La}_{x} \mathrm{Fe}_{12} \mathrm{O}_{19}$ for $\mathrm{x}=0$ and $\mathrm{x}=$ $0-1$, while for the composition of $\mathrm{x}=0.2$, the sample cannot react thoroughly, namely the $\mathrm{Ba}_{1-\mathrm{x}} \mathrm{La}_{x} \mathrm{Fe}_{12} \mathrm{O}_{19}$ phase and $\mathrm{Fe}_{2} \mathrm{O}_{3}$, and the rest is for the composition $0.2<\mathrm{x}<0.7$. The sample also cannot react completely and consists of three phases, namely $\mathrm{Ba}_{1-\mathrm{x}} \mathrm{La}_{x} \mathrm{Fe}_{12} \mathrm{O}_{19}, \mathrm{Fe}_{2} \mathrm{O}_{3}, \mathrm{and}_{\mathrm{LaFeO}}$ phases. The phase identification results are very intriguing to be comprehended. For $\mathrm{x}=0.1$, it shows that the lanthanum atoms have succeeded in replacing some of the $\mathrm{Ba}$ atoms in the $\mathrm{BaFe}_{12} \mathrm{O}_{19}$ structure. In Figure 1, it also appears that increasing the La content $(\mathrm{x}>0.2)$ in the sample causes the presence of $\mathrm{Fe}_{2} \mathrm{O}_{3}$ and $\mathrm{LaFeO}_{3}$ phases to increase. Meanwhile, the quantitative analysis uses GSAS software and uses Crystallography Open Database as reference data.

Based on the refinement of the X-ray diffraction pattern results of the $\mathrm{Ba}_{1-x} \mathrm{La}_{\mathrm{x}} \mathrm{Fe}_{12} \mathrm{O}_{19}$ sample with composition variations of $(\mathrm{x}=0-0.7)$ using GSAS software $[23,24]$. The data analysis results confirm that the samples have a single phase in its composition $x=0$ and $x=0.1$ $\left(\mathrm{Ba}_{0.9} \mathrm{La}_{0.1} \mathrm{Fe}_{12} \mathrm{O}_{19}\right)$. At the composition $\mathrm{x}=0.1,10 \% \mathrm{La}$ atoms replace some $\mathrm{Ba}$ atoms, expecting to have an influence on the physical and chemical properties. In this case, the analysis of the cationic distribution at the Ba atomic site is essential to be carried out by defining each Ba site's atomic occupancy factor that has been added $\mathrm{La}$. The $\mathrm{Ba}_{1-x} \mathrm{La}_{x} \mathrm{Fe}_{12} \mathrm{O}_{19}$ structure is hexagonal with a $\mathrm{P} 63 / \mathrm{mmc}$ space group. The Ba atom occupies the Wyckoff on site 2d, while La atom takes off the Wyckoff on the same site on-site 2d. One unit cell $\mathrm{Ba}_{1-\mathrm{x}} \mathrm{La}_{\mathrm{x}} \mathrm{Fe}_{12} \mathrm{O}_{19}$ where the Fe ion is arranged in the bipyramidal (2b) and octahedral $(2 \mathrm{a}, 12 \mathrm{k})$ trigonal plane with a spin orientation parallel to the Fe ion in the $4 \mathrm{f}$ plane [25]. Part of the Wyckoff position of the Ba atom at site $2 \mathrm{~d}$ will be occupied by atom La. The cationic distribution of the refinement results shows that part of the $\mathrm{Ba}_{2}{ }^{+}$ion at the site (2d) has been successfully substituted by the $\mathrm{La}^{3+}$ ion of 11 at $\%$ in the composition $\mathrm{x}=0.1$, so based on the refinement results of the cationic distribution, the empirical formula for $\mathrm{x}=0.1 \mathrm{is} \mathrm{Ba}_{0.9} \mathrm{La}_{0.1} \mathrm{Fe}_{12} \mathrm{O}_{19}$. This result is slightly different from Zhiyong Pang's research which has succeeded in substituting La into $\mathrm{Sr}$ up to $\mathrm{x}=0.3$. It is assumed that the difference in ionic radius of $\mathrm{Ba}^{2+}$ is greater than that of $\mathrm{Sr}^{2+}[22]$.

In this study, some of the Ba ion positions are replaced by La ions as a function of the $\mathrm{x}$ composition through the cation substitution method. Since La has a valence of 3+, it is also thought that it can affect the oxygen content of the sample, which can only be analyzed using a neutron diffraction facility, while XRD cannot define oxygen content. In Figure 2 (a), it can be seen that for $x=0.1$, the crystal volume is observed to decrease because the atomic radius of La $(r=1.69 \AA)$ is shorter than those of $B a(r=1.98 \AA)$. Besides, for the composition $x>0.1$, the crystal volume steadily decreases, which is thought to be caused by lattice distortion. The inclusion of excess La $(x>0.1)$ produces an imbalance of the reaction so that $\mathrm{La}$ prefers to bind $\mathrm{Fe}$ to form $\mathrm{LaFeO}_{3}$ because the compound composition is comparatively stable compared to $\mathrm{LaFe}_{12} \mathrm{O}_{19}$. Meanwhile, other $\mathrm{Fe}$ will bind $\mathrm{O}$ to form $\mathrm{Fe}_{2} \mathrm{O}_{3}[26]$.
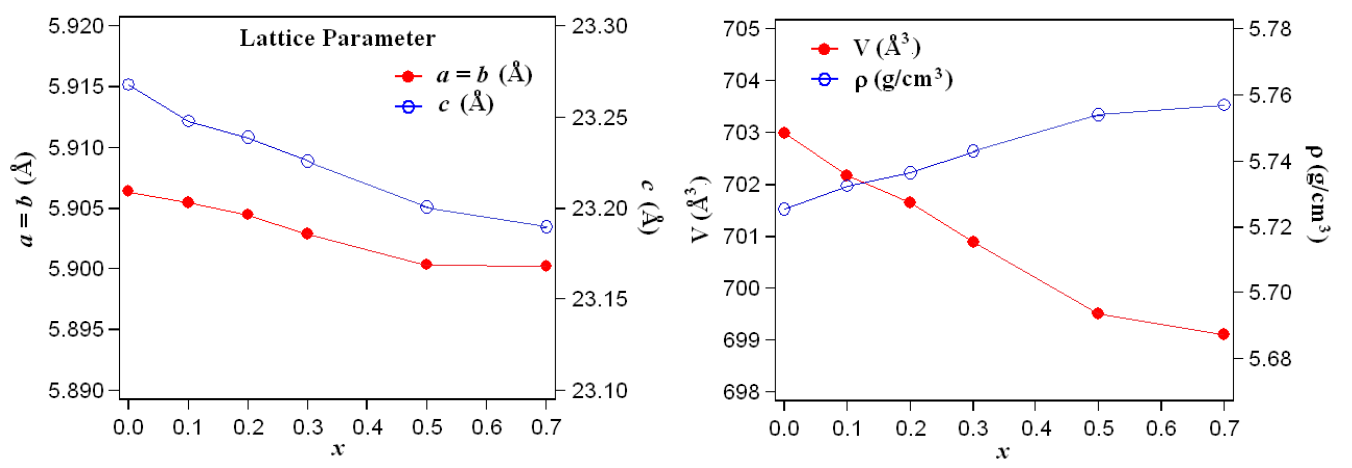

Fig. 2. The analysis of $\mathrm{Ba}_{1-x} \mathrm{La}_{x} \mathrm{Fe}_{12} \mathrm{O}_{19}$

The crystallite size and lattice strain were calculated from the $\mathrm{W}-\mathrm{H}$ (Williamson-Hall) plot for the 5 highest peaks of the XRD pattern using the equation $\beta \cos \theta=\mathrm{k} \lambda / D+4 \varepsilon \sin \theta$ [27]. In which $\mathrm{k}$ is the constant (0.9), $\lambda$ is the X-ray wavelength, $\theta$ is the Braggs diffraction angle, $\mathrm{D}$ is the crystallite size, $\beta$ is FWHM, and $\varepsilon$ is the lattice strain. The curves $\beta \cos \theta$ versus $\sin \theta$ for the XRD patterns of the $\mathrm{Ba}_{1}-{ }_{\mathrm{x}} \mathrm{La}_{\mathrm{x}} \mathrm{Fe}_{12} \mathrm{O}_{19} \mathrm{sample} \mathrm{x}=0$ 
and $x=0.1$ ) are presented in Figures $3(a)$ and (b). The data were analyzed following the linear function of the curve $\beta$ cos $\theta$ versus sin $\theta$. The lattice strain was calculated from the ordinate interception, while the crystallite size was obtained from the slope of the linear functional analysis. It was observed that the mean crystal size was almost consistent for all samples; that is, it varied over a narrow range ( \pm 138 nm). It should be noted that the lattice strain increases with increasing $\mathrm{La}^{3+}$ concentration in barium hexaferrite. This can be originated from the smaller ionic radius of $\mathrm{La}^{2+}(1.69 \AA)$ compared to $\mathrm{Ba}^{2+}(1.98 \AA)$. This also shows that the $\mathrm{La}^{3+}$ ionic radius is smaller than that of $\mathrm{Ba}^{2+}$, so that the unit cell volume also decreases.

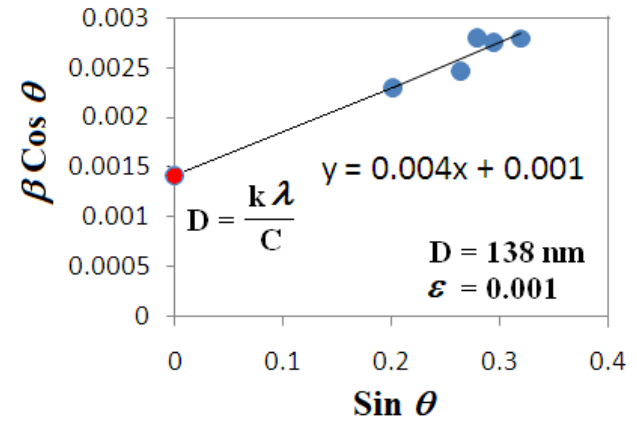

(a) $x=0$

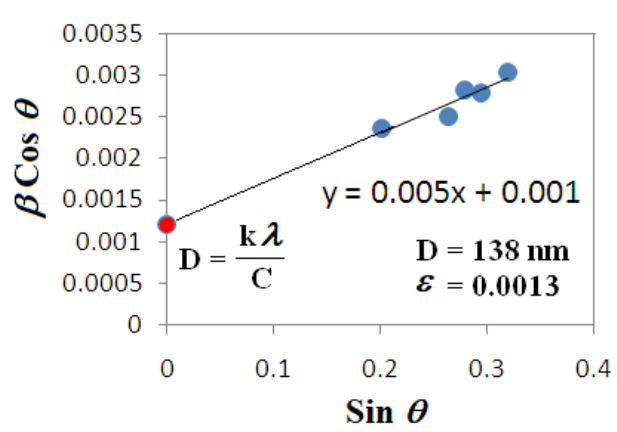

(b) $\mathrm{x}=0.1$

Fig. 3. Crystallite size and lattice strain of $\mathrm{Ba}_{1-x} \mathrm{La}_{x} \mathrm{Fe}_{12} \mathrm{O}_{19}$ for $\mathrm{x}=0$ (a) and $\mathrm{x}=0.1$ (b)

Figure 4 shows that the particle morphology for $\mathrm{x}=0$ tends to be uniform with the polygonal shape sizing from $500 \mathrm{~nm}$ to 1000 $\mathrm{nm}$. Similar to the particle morphology for the composition of $\mathrm{x}=0.1$, it has good and uniform homogeneity with the polygonal particle shape and relatively uniform particle size, but relatively smaller than the composition $\mathrm{x}=0$ from $400 \mathrm{~nm}$ to $800 \mathrm{~nm}$. In general, our findings correspond to Zhiyong's research on single-phase polycrystalline samples with homogeneity particle shape [22]. Meanwhile, for the composition of $x>0.1$, it was found that different particle shapes were found with very large particle sizes of about $1.5-2 \mathrm{~mm}$, which were thought to be particles from other phases. According to the XRD data refinement results, there are two other possible phases, namely the $\mathrm{Fe}_{2} \mathrm{O}_{3}$ phase or the $\mathrm{LaFeO}_{3}$ phase.

In addition, Figure 5 shows the resume of measurements of magnetic properties using a vibrating sample magnetometer in the

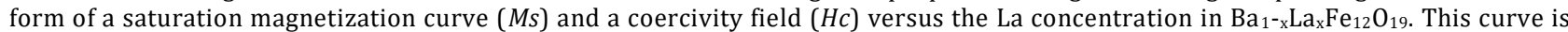
taken from the results of the hysteresis curve, by which magnetization and the external magnetic field $\mathrm{H}$ correlate with each other. $\mathrm{Ba}_{1}$ ${ }_{x} \mathrm{La}_{x} \mathrm{Fe}_{12} \mathrm{O}_{19}$ consists of two molecules containing 64 ions at 11 different locations. The total net magnetic moment is $20 \mu \mathrm{B}$ per unit cell. The magnetic properties strongly depend on the cationic distribution that can be controlled from its arrangement. However, it is different if the magnetic properties of the barium hexaferrite are disturbed; the crystallographic site is disturbed so that it does not only rely on the cationic distribution but also on the lattice strain.

The $M s$ value tends to increase from $0.250 \mathrm{kA} / \mathrm{m}$ to $255 \mathrm{kA} / \mathrm{m}$ while the $H c$ value tends to decrease from $3.59 \mathrm{kOe}$ to $3.42 \mathrm{kOe}$ with increasing La concentration. The $M s$ increases due to the increase in the lattice strain with the substitution of La for $\mathrm{x}=0.1$. The lattice strain arises because of the smaller atomic radius of $\mathrm{La}^{2+}(1.69 \AA)$ compared to $\mathrm{Ba}^{2+}(1.98 \AA \AA)$. The lattice strain advances by more than $10 \%$ La substitution in $\mathrm{Ba}_{1-x} \mathrm{La}_{x} \mathrm{Fe}_{12} \mathrm{O}_{19}$, the $\mathrm{Ms}$ and $\mathrm{Hc}$ decrease, as the Fe site is placed by La. Besides, it is known that the mass fraction of the $\mathrm{Ba}_{1-x} \mathrm{La}_{x} \mathrm{Fe}_{12} \mathrm{O}_{19}$ phase decreases along with the increasing La atom. Therefore, the analysis indicates that the increasing magnetic properties for La substitution can be achieved for a $10 \%$ composition. It can be explained by considering the lattice strain as well as the decrease in $\mathrm{Fe}-\mathrm{O}-\mathrm{Fe}$ exchange interactions due to off-centering of the $\mathrm{La}^{3+}$ ion.

a)

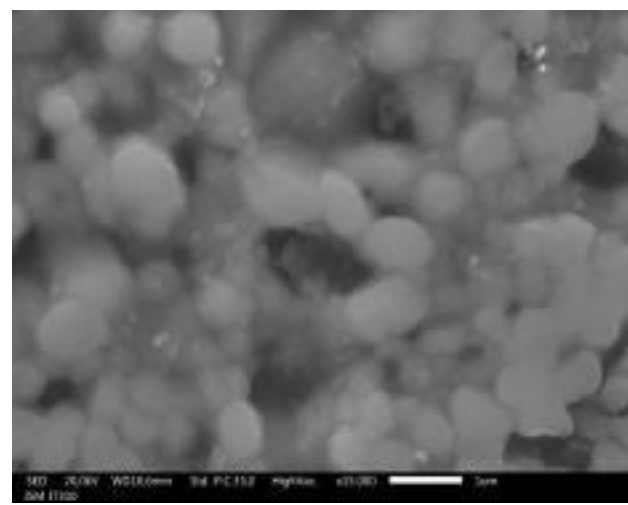

b)

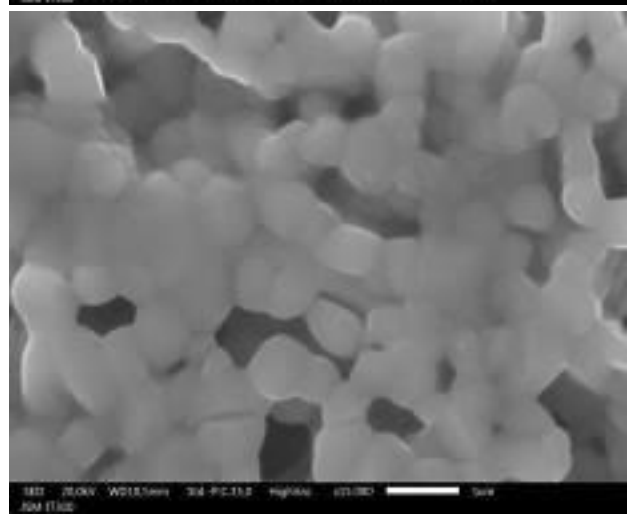

c)

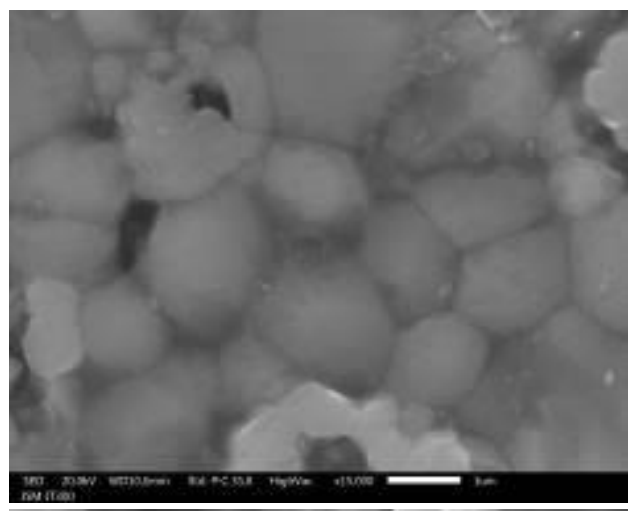

d)

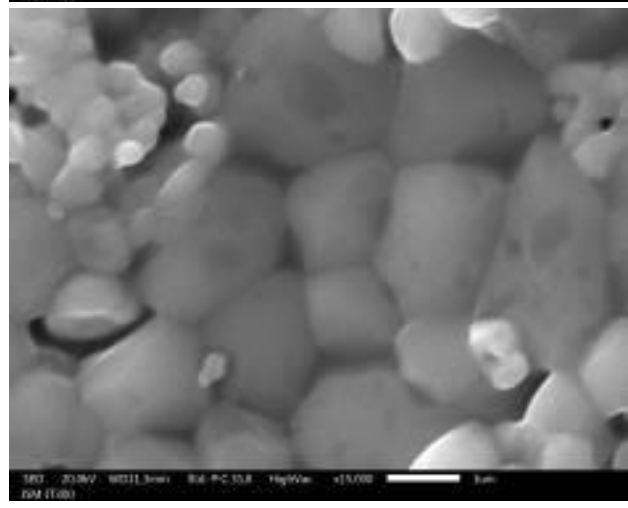

Fig. 4. Particle morphology of $\mathrm{Ba}_{1-\mathrm{x}} \mathrm{La}_{x} \mathrm{Fe}_{12} \mathrm{O}_{19}$ observed using SEM a) $\mathrm{x}=0$; b) $\mathrm{x}=0.1$; $\mathrm{c}$ ) $\mathrm{x}=0.5$; dan $\mathrm{d}$ ) $\mathrm{x}=0.7$ 


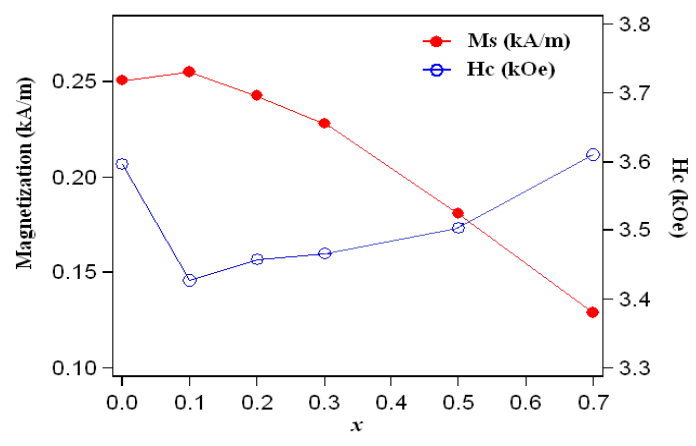

Fig. 5. Ms and $H c$ of $\mathrm{Ba}_{1-\mathrm{x}} \mathrm{La}_{\mathrm{x}} \mathrm{Fe}_{12} \mathrm{O}_{19}$

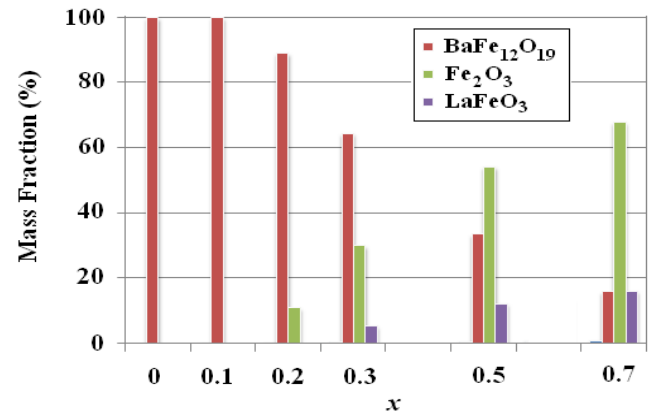

Fig. 6. Mass fraction of XRD refinement for $\mathrm{Ba}_{1-\mathrm{x}} \mathrm{La}_{\mathrm{x}} \mathrm{Fe}_{12} \mathrm{O}_{19}$

\section{Conclusions}

Synthesis of $\mathrm{Ba}_{1-\mathrm{x}} \mathrm{La}_{\mathrm{x}} \mathrm{Fe}_{12} \mathrm{O}_{19}$ using variations in composition $(\mathrm{x}=0-0,7)$ has been successfully carried out. The refinement of the $\mathrm{X}$-ray diffraction pattern shows that the La substitution has been successfully carried out and has a single phase in the composition $\mathrm{x}=0\left(\mathrm{Ba}_{1}\right.$. $\left.{ }_{x} \mathrm{La}_{x} \mathrm{Fe}_{12} \mathrm{O}_{19}\right)$ dan $\mathrm{x}=0,1\left(\mathrm{Ba}_{1-x} \mathrm{La}_{x} \mathrm{Fe}_{12} \mathrm{O}_{19}\right)$. The substitution results showed that the crystallite size was fixed, but the increasing La concentration occurs while the lattice strain increased. In contrast, for compositions $x>0.1$, the different particle shapes are found with larger particle sizes. The saturation magnetization increases while the coercivity field decreases after substituting La for $\mathrm{x}=0.1$, then the saturation magnetization decreases while the coercivity field increases with increasing La concentration for $x>0.1$. Thus, the La substitution into barium hexaferrite can affect its structural and magnetic properties.

\section{Acknowledgements}

This work was supported by Center for Electronic and Telecommunication (Indonesian Institute of Sciences) and Center for Science and Technology of Advanced Materials (Kawasan Puspiptek Serpong), Indonesia, for providing research facilities.

\section{References}

[1] X. Shen, F. Song, J. Xiang, M. Liu, Y. Zhu, and Y. Wang, "Shape anisotropy, exchange-coupling interaction and microwave absorption of hard/soft nanocomposite ferrite microfibers," J. Am. Ceram. Soc., vol. 95, no. 12, pp. 3863-3870, 2012.

[2] B. F. Phelps, F. Liorzou, and D. L. Atherton, “Inclusive model of ferromagnetic hysteresis," IEEE Trans. Magn., vol. 38, no. 2, pp. 1326-1332, 2002.

[3] R. C. Pullar, "Hexagonal ferrites: a review of the synthesis, properties and applications of hexaferrite ceramics," Prog. Mater. Sci., vol. 57, no. 7, pp. 1191-1334, 2012.

[4] A. Bahadur et al., "Morphological and magnetic properties of $\mathrm{BaFe}_{12} \mathrm{O}_{19}$ nanoferrite: A promising microwave absorbing material," Ceram. Int., vol. 43, no. 9, pp. 7346-7350, 2017.

[5] Z. P. Wu et al., "Electromagnetic interference shielding of carbon nanotube macrofilms," Scr. Mater., vol. 64, no. 9, pp. 809-812, 2011.

[6] A. Kumar, S. S. Yadava, P. Gautam, A. Khare, and K. D. Mandal, "Magnetic and dielectric studies of barium hexaferrite (BaFe $\left.12 \mathrm{O}_{19}\right)$ ceramic synthesized by chemical route," J. Electroceramics, vol. 42, no. 1, pp. 47-56, 2019.

[7] V. C. Chavan, S. E. Shirsath, M. L. Mane, R. H. Kadam, and S. S. More, "Transformation of hexagonal to mixed spinel crystal structure and magnetic properties of $\mathrm{Co}^{2+}$ substituted $\mathrm{BaFe}_{12} \mathrm{O}_{19}$, " J. Magn. Magn. Mater., vol. 398, pp. 32-37, 2016.

[8] W. S. Castro, R. R. Corrêa, P. I. Paulim Filho, J. M. R. Mercury, and A. A. Cabral, "Dielectric and magnetic characterization of barium hexaferrite ceramics," Ceram. Int., vol. 41, no. 1, pp. 241-246, 2015.

[9] J. R. Liu, M. Itoh, T. Horikawa, M. Itakura, N. Kuwano, and K. Machida, "Complex permittivity, permeability and electromagnetic wave absorption of $\alpha$-Fe/C (amorphous) and $\mathrm{Fe}_{2} \mathrm{~B} / \mathrm{C}$ (amorphous) nanocomposites," J. Phys. D. Appl. Phys., vol. 37, no. 19, p. 2737, 2004.

[10] W. A. Adi and A. Manaf Ridwan, "Absorption characteristics of the electromagnetic wave and magnetic properties of the La $0.8 \mathrm{Ba}_{0.2} \mathrm{Fe}_{\mathrm{x}} \mathrm{Mn}_{1 / 2(1-\mathrm{x})} \mathrm{Ti}_{1 / 2(1-\mathrm{x}) 03}(\mathrm{x}=0.1-$ 0.8) Perovskite system," Int. J. Technol., vol. 5, pp. 887-897, 2017.

[11] F. M. M. Pereira et al., "Structural and dielectric spectroscopy studies of the M-type barium strontium hexaferrite alloys ( $\left.\mathrm{Ba}_{x} \mathrm{Sr}_{1-\mathrm{x}} \mathrm{Fe}_{12} \mathrm{O}_{19}\right)$," J. Mater. Sci. Mater. Electron., vol. 19, no. 7, pp. 627-638, 2008.

[12] M. B. Kaynar, S. Özcan, and S. I. Shah, "Synthesis and magnetic properties of nanocrystalline $\mathrm{BaFe}_{12} \mathrm{O}_{19}$," Ceram. Int., vol. 41, no. 9, pp. 11257-11263, 2015.

[13] R. E. El Shater, E. H. El-Ghazzawy, and M. K. El-Nimr, "Study of the sintering temperature and the sintering time period effects on the structural and magnetic properties of M-type hexaferrite $\mathrm{BaFe}_{12} \mathrm{O}_{19}$," J. Alloys Compd., vol. 739, pp. 327-334, 2018.

[14] Ü. Özgür, Y. Alivov, and H. Morkoç, “Microwave ferrites, part 1: fundamental properties," J. Mater. Sci. Mater. Electron., vol. 20, no. 9, pp. 789-834, 2009.

[15] M. N. Ashiq, M. J. Iqbal, M. Najam-ul-Haq, P. H. Gomez, and A. M. Qureshi, "Synthesis, magnetic and dielectric properties of Er-Ni doped Sr-hexaferrite nanomaterials for applications in High density recording media and microwave devices," J. Magn. Magn. Mater., vol. 324, no. 1, pp. 15-19, 2012.

[16] D. A. Vinnik et al., "Tungsten substituted $\mathrm{BaFe}_{12} \mathrm{O}_{19}$ single crystal growth and characterization," Mater. Chem. Phys., vol. 155, pp. 99-103, 2015.

[17] Y. E. Gunanto, E. Jobiliong, and W. A. Adi, "Composition and phase analysis of nanocrystalline $\mathrm{Ba}_{\mathrm{x}} \mathrm{Sr}_{1-\mathrm{x}} \mathrm{Fe}_{12} \mathrm{O}_{19}(\mathrm{x}=1.0$; 0.6 ; and 0.4$)$ by using general structure analysis system," in AIP Conference Proceedings, 2016, vol. 1719, no. 1, p. 30019.

[18] H. Nikmanesh, S. Hoghoghifard, and B. Hadi-Sichani, "Study of the structural, magnetic, and microwave absorption properties of the simultaneous substitution of several cations in the barium hexaferrite structure," J. Alloys Compd., vol. 775, pp. 1101-1108, 2019.

[19] H. Sözeri, Z. Mehmedi, H. Kavas, and A. Baykal, "Magnetic and microwave properties of $\mathrm{BaFe}_{12} \mathrm{O}_{19}$ substituted with magnetic, non-magnetic and dielectric ions," Ceram. Int., vol. 41, no. 8, pp. 9602-9609, 2015.

[20] V.Zepf, Rare earth elements: a new approach to the nexus of supply, demand and use: exemplified along the use of neodymium in permanent magnets. Springer 
Science \& Business Media, 2013.

[21] W. A. Adi, S. Wardiyati, and S. H. Dewi, "Nanoneedles of Lanthanum Oxide $\left(\mathrm{La}_{2} \mathrm{O}_{3}\right)$ : A Novel Functional Material for Microwave Absorber Material," in IOP Conference Series: Materials Science and Engineering, 2017, vol. 202, no. 1, p. 12066.

[22] Z. Pang, X. Zhang, B. Ding, D. Bao, and B. Han, “Microstructure and magnetic microstructure of La+ Co doped strontium hexaferrites," J. Alloys Compd., vol. 492, no. 1-2, pp. 691-694, 2010.

[23] B. H. Toby, "EXPGUI, a graphical user interface for GSAS," J. Appl. Crystallogr., vol. 34, pp. 210-213, 2001.

[24] M. S. Idris and R. A. M. Osman, "Structure refinement strategy of Li-based complex oxides using GSAS-EXPGUI software package," in Advanced Materials Research, 2013, vol. 795, pp. 479-482.

[25] L. S. I. Liyanage, S. Kim, Y.-K. Hong, J.-H. Park, S. C. Erwin, and S.-G. Kim, "Theory of magnetic enhancement in strontium hexaferrite through Zn-Sn pair substitution," J. Magn. Magn. Mater., vol. 348, pp. 75-81, 2013.

[26] S. S. S. Afghahi, M. Jafarian, M. Salehi, and Y. Atassi, "Improvement of the performance of microwave X band absorbers based on pure and doped Ba-hexaferrite," J. Magn. Magn. Mater., vol. 421, pp. 340-348, 2017.

[27] D. Nath, F. Singh, and R. Das, "X-ray diffraction analysis by Williamson-Hall, Halder-Wagner and size-strain plot methods of CdSe nanoparticles-a comparative study," Mater. Chem. Phys., vol. 239, p. 122021, 2020. 